ARTICLE

DOI: $10.1057 /$ s41599-017-0034-z

\title{
Othering in Chinese official media narratives during diplomatic standoffs with the US and Japan
}

Lutgard Lams ${ }^{1}$

\begin{abstract}
Based on two critical discourse analyses of Chinese media narratives on international incidents between China and the foreign 'Other' with an interval of nine years, this paper demonstrates continuity and consistency in Chinese official media discourse over the last decade when it concerns sensitive matters, such as sovereignty. The two case studies offered are: the 2001 diplomatic standoff with the US following the spy plane collision; and the 2010 conflict with Japan over the Chinese fishing boat collision with the Japanese coastal guard in the disputed waters of the Diaoyutai/Senkaku Islets. Using theoretical insights and methodological tools from Language Pragmatics, Critical Discourse Theory and Analysis, and Positioning Theory, these studies find identical official Chinese media practices of Othering and self-glorification. The article presents concrete examples of categorizing processes that position the actors as antagonists within a victim/aggressor framework, discursive ideological mechanisms of reification, legitimation, dramatization and generalization, and linguistic power games through the employment of assertive speech acts.
\end{abstract}

${ }^{1}$ KU Leuven Campus Brussel, Brussel, Belgium. Correspondence and requests for materials should be addressed to L.L. (email: lut.lams@kuleuven.be) 


\section{Introduction}

t times of destabilizing events in a community's history when the nation is perceived to be threatened by external and/or internal forces, attempts are usually made at reinforcing sensations of shared values and cultural/national identities. Examples of such critical moments for China are not only internal schisms interrogating the sense of the unified Self, but especially conflicts with a foreign outsider, such as the incidents of the 2001 diplomatic standoff with the US following the spy plane collision near Hainan Island and the 2010 conflict with Japan concerning the Chinese fishing boat collision with the Japanese coastal guards in the disputed waters of the Diaoyutai/ Senkaku Islets. ${ }^{1}$ The present article traces discursive patterns of positioning the Self and the Other in Chinese official media narratives about the 2001 and 2010 incidents, since they both involve issues of sovereignty and disputes about responsibility. It compares findings of two discourse-analytical studies about these media accounts to map continuities and consistencies in Chinese official discourse about sensitive matters, such as sovereignty, over a span of nine years. In demonstrating consistency in Chinese official discourse on these issues, in terms of manifest content and latent meanings as well as formal linguistic strategies, it is hoped to reach a better understanding of where China draws a red line in international relations and of its strategic moves as a geopolitical player.

Using insights from linguistic pragmatics, Critical Discourse Analysis/Theory, and narrative/ positioning theory, these two case studies, which analyze media accounts with an interval of 10 years, examined linguistic tools of alienation and empowerment in the Chinese official press narratives. The corpus for the 2001 collision comprised the Chinese-language Renmin Ribao, its English equivalent The People's Daily, the English-language China Daily, and the Beijing Review, an English-language (official) propaganda magazine. For the 2010 case study, ideological positioning was traced in the articles from the Chinese-language Renmin Ribao and its English-language equivalent, the People's Daily.

The article starts with an outline of theoretical premises and the methodological framework for the analyses of both corpora. After a brief contextualization of the two incidents, results of the empirical case studies are presented in two parts. A first subsection reveals categorization processes of actors (polarized positioning of the in/outgroups), while the second one zooms in on other discursive mechanisms, such as dramatization, generalization, legitimation and reification processes. The article next uncovers possible reasons underlying the representational practices, reflects upon new developments in cultural discourse studies, and concludes with a summary of the main points of continuity in the discourse while also pointing out implications of the patterns found.

\section{Theoretical and methodological observations}

Central in this study is the way the Chinese official media narratives engage in 'Othering' when representing the American and Japanese Other during critical times of diplomatic standoffs with these foreign nations. The critique of certain (media) misrepresentations is considered as one of the most influential topics in Cultural Studies (Brantlinger, 1990). It is largely inspired by postcolonial literature and cultural theorists like Edward Said, who in his seminal work Orientalism designated the Other as a form of cultural projection of concepts. According to Said, Orientalism depends for its strategy on a flexible (Western) positional superiority, which puts the Westerner in a whole series of possible relationships with the Orient without ever losing him the relative upper hand (Said, 1978, 2003, p 7). It is the nature of this 'flexible positional superiority', which lies at the basis of the 'Othering' process (Edgar and Sedgwick, 1999, p 266). The current study aims to complement the debate on Western misrepresentation of the Other by critically assessing the Chinese media performance in representing the foreign Other.

The term 'Othering' denotes the process of 'heteronomization' (Wodak et al., 1999) or discursively constructing a common denominator for collective identification of a group that is seen as different from the constructed 'ingroup' and depicted as a threatening stranger. According to the discourse theorists Laclau and Mouffe (1985), boundaries of exclusion and inclusion are drawn along 'chains of equivalence and difference'. In the process of Othering as the 'codificiation of difference' (Said, 1978), the Self is ascribed an identity through the often negative attribution of features to the Other. Central to the structuring of the Self, which in the political realm relates to the political process of nation-building, is the development of a hostile image of the Other.

Critical discourse analysis uncovers how a polarizing discursive activity highlights the negative aspects of the Other and the positive attributes of the Self while marginalizing the positive features of the Other and the negative actions or characteristics of the Self. This discursive formation of polarization corresponds with what Van Dijk has termed the 'ideological square' (Van Dijk, 1998, p 267). Very often, the negative portrayal of the Other in the media accounts serves as an assertion of the national Self.

Preconceived ideas of differences and similarities between them and us preclude the negotiability and fluidity of identities and reduce the dynamic relationship between in/outgroups in static descriptions. Particular perceptions get fixed as simplifications, which easily become taken-for-granted assumptions through social and discursive exchange. In simplifying the openness of meaning, the foreign Other is reduced to essentialist stereotypes. The beliefs we have about the Other are, to a large extent, circulated by the media. They can easily become 'common sense' characterizations of the Other without being questioned. However, they can also be instrumental for those in power, who intentionally deploy them as ideological arguments to legitimize their perspective. Once this position has become consensual, those who have everything to gain by categorizing the world in a certain way will struggle to keep their meanings mainstream or dominant and therefore, hegemonic. Since the 'chains of equivalence and difference' (Laclau and Mouffe, 1985) are never closed, a full identity is illusory but is presented as a static entity to secure itself against the utterly contingent nature of identities, ever at risk of being renegotiated. In China, official discourses are centered on the belief of its nation constantly subjected to internal and external threats. Therefore, the discourse of unity is essential to forge a full identity, strengthen the chains of equivalence and avoid renegotiation of the Chinese identity by alternative voices.

As for the methodological approach to the media analysis, the studies drew on the insights from Pragmatics, where the study of relations between language and context is deemed essential to an account of language understanding (Levinson, 1983; Verschueren, 1999; Mey, 2001). Hence, text and talk should always be examined within their production context in its widest (political, social, and cultural) sense (Verschueren, 1999, 2001). Besides the linguistic context (e.g., collocations, textual cohesion markers and structural ordering on the sentential and textual level), the analyst needs to examine wider aspects of political and cultural structures and relations, since these inform 'social cognition', 'mental scripts' (Van Dijk, 1989, 1995). In addition, one ought to consider the immediate mental, social and physical world of the utterer/ interpreter, the institutional production setting, the specific characteristics of news discourse as well as the media system in 
which the media organizations operate (Verschueren, 1999). For example, a specific property of hard news coverage in Western media systems is the news value of negativity, which does not usually fit the cultural climate within which the Chinese news media operate when reporting news, especially about the ingroup. Media organizational processes also determine to what extent news workers are subject to practical restrictions. Elements such as limited access to the events and newsmakers, conflicting forces during the story's production by journalists and copyeditors, issues of (self)censorship all deserve due consideration. In addition, the analyst needs to understand the function and daily routines of the media outlets analyzed. The (Chinese-language) Renminribao, the People's Daily, the China Daily, and the Beijing Review are widely seen as mouthpieces of the Chinese Communist Party, are subject to party control and are primarily staffed by Chinese journalists, copy-writers and editors. While this paper cannot detail all these contextual factors, it outlines the situational context of the two case studies and offers a brief discussion of the cultural and historical context of the discourses.

The textual analyses started from the premise that meaning is generated on an explicit and implicit level. Analyzing this meaning generation process involves examining modes of ideological operation through discursive strategies of symbolic construction (Thompson, 1990). The present article draws on Thompson's list of symbolic strategies, such as legitimation and reification, both of which have been shown to operate in Chinese official discourse (Lams, 2014). Legitimation sanctions certain actions by rationalizing or constructing a chain of reasoning to defend a set of social relations (Carvallo, 2008; Van Leeuwen and Wodak, 1999). Reification or naturalization takes place when essentialist discourse represents a transitory state of affairs as if it were natural and permanent while eliminating its social and historical character and denying the contingency of social processes (Lams, 2010). Naturalization of discourse presents contingent structures, processes or meanings as natural and lies at the core of ideological media representations of reality (Allan, 1999). At the text writing stage, linguistic choices are made from a range of alternatives. As Hartley puts it, "the multi-accentual 'potential for meaning' of the chosen signs" are filled in "until the signs are 'closed', apparently uni-accentual" (Hartley, 1982, p 63). Critical discourse studies identify the discursive means of this 'ideological closure' (Hartley, 1982, p 63), which requires intensive interpretive work (Carvallo, 2008).

Besides the discourse strategies of legitimation and naturalization, other meaning generation interventions are also examined, such as positioning, dramatization, and generalization. Positioning is a discourse strategy that constructs social actors or groups into certain relationships with others and constitutes their identity. The theory of narrative positioning operates, according to Bamberg (1997) on three levels: (1) positioning of characters in relation to one another (e.g., as perpetrators and victims); (2) positioning of speaker position to the audience (e.g., instructing the listener, making excuses, attributing blame); (3) positioning of the narrator to the Self (constructing self-identity). A certain positioning of actors may entitle them to do certain things and thus bestows authority on some while depriving agency of others. This positioning also forms an integral part of the interpersonal function of language in the Hallidayan systemic-functional view of language $(1978,1994)$. Any consistent categorization or classifying system of groups effaces individuality and totalizes the discourse, reaching closure and thereby excluding alternative discourses. Categorization happens in many ways, such as choosing heavily value-laden labels, stereotypes, euphemisms, metaphorization. Based on the Hallidayan approach to language, an "analysis of consistent transitivity patterns in propositions about the world in which an event, situation, relation or attribute is predicated of participants can disclose how these patterns may encode mental pictures of reality" (Halliday, 1994, p 106). A consistent attribution of active/passive agency roles to certain groups, in addition to positive/negative connotational semantics involved in the action, creates conceptual polarization of in- and outgroups.

Generalization embeds a single event in a larger national and historical context and subsumes different items under one general heading. Dramatization is achieved by a focus on human interest stories and the victimhood of the actor, be it a nation and/or individuals. These narratives foreground personal loss and grief and thus aim to engage the reader's empathy with the victim.

Conclusions about ideological investment of texts are only drawn when certain patterns are traceable across a variety of linguistic structures at the macro/micro level (Verschueren, 2001; Van Dijk, 1998). The macro perspective includes global meaning constructs at a textual level, like layout, patterns of rhetorical argumentation, thematic hierarchies (practices of highlighting, omission) and headlines, which have the potential to activate certain interpretive frameworks. Structural elements approached from a micro-perspective will be discussed at the word (connotational semantics), as well as sentential level (syntax, modality). The most widely studied form of ideological expression in discourse is the systematic choice of lexicons and lexical patterns (Lams, 2010, p 106). Words can be imbued with strong positive/ negative connotation or have a vague semantic content. Overlexicalization arises when a number of interrelated terms in the same semantic field co-occur. Consistent repetition of lexical items belonging to a semantic field with positive connotation in descriptions of the 'us' group can implicitly create a negative image of the 'other', who is usually associated with a contrasting set of terms.

For the first study about the spy plane collision, two sets of corpora were used. The Chinese-language corpus ran from 2-25 April 2001 and was compiled through a manual newspaper search yielding 123 articles from the Renminribao [RMRB] with a random selection of 23 sample articles for close analysis (17 news and 6 commentaries). The second corpus included all 157 headlines of the RMRB's English-language equivalent, the People's Daily [PD], all 58 op-ed and news articles from the Englishlanguage China Daily [CD], and all 18 articles of the Beijing Review (magazine). The period selected ran from 2 April to 22 April, starting from the day after the event occurred until saturation of the news coverage. ${ }^{2}$ Both corpora were analyzed for their discursive features concerning categorization processes of us/them groups, but only the second corpus underwent a frequency analysis to provide quantitative data for certain findings. Therefore, the present paper primarily reports data from the second corpus analysis, the results of which run parallel to findings from the first corpus investigation.

Selection for the corpus of the second case-study, the Chinese/ Japanese fishing boat incident in 2010, happened on the basis of a keyword search ('D/Tiaoyutai Islands') in the online database of the People's Daily (PD) and a manual search through the Chinese-language Renminribao (RMRB) newspaper. The period analyzed ran from 8 to 26 Sept 2010, the day following the incident (7 Sept) until two days after the release of the Chinese fishing boat captain (24 Sept). The crew had been released 11 days earlier. The corpora for the $P D$ and $R M R B$ yielded 35 and 16 articles respectively.

Descriptions of the two incidents: US/Chinese plane collision 2001; Japanese/Chinese boat collision 2010 US/Chinese plane collision leading to the diplomatic standoff between China/US (April 2001). On 1 April 2001, a collision 
between two military planes-an American Navy EP-3E surveillance aircraft with 24 crew members and a Chinese F-8 jet fighter-occurred over the South China Sea. The Chinese jet fighter crashed and the pilot, Wang Wei, went missing despite extensive search operations. Soon after the accident, the American plane made an emergency landing at the nearest Chinese military airport on Hainan Island. The 24 crew members were detained in the military compound on Hainan Island. The Chinese authorities instantly blamed the American plane for 'ramming and destroying' their fighter and illegally intruding into Chinese airspace by landing at the airport without verbal clearance. Hence, China demanded that the US government apologize and accept full responsibility. The latter refused, standing firm in their conviction that the American pilot was not to blame. The accident gave rise to a 11-day diplomatic standoff between China and the US, both sides resorting to international treaties to legitimize their contradictory claims. The crew were only released after the US had slightly modified its initial letter of regret for the loss of the pilot, into a formulation that was acceptable to both parties. Moreover, a creative Chinese translation of the official letter was spread through the Chinese media. The Chinese language has a range of terms for 'sorry' with varying illocutionary force from a light regret to a sincere apology. Through the selection of the word with the heaviest apologetic force, the official media aimed to convince the Chinese readership that the US had actually assumed full responsibility.

No hard evidence was presented of the collision's circumstances. Hence, the event and its ensuing diplomatic stand-off between the US and China gave rise to multiple interpretations by government officials. Points of contention involved, amongst others, the responsibility for the collision and the precise location of the event. The Chinese leadership argued it had happened in Chinese airspace whilst the American officials insisted it occurred above international waters. An in-depth survey into the international legal aspects of both the Chinese and American claims is provided by Lewis (2002).

The official American position concerning guilt attribution held that no comments could be made until the crew had been heard and a joint investigation into the collision had been set up. But the US media reported speculations within the US military that the Chinese jet had caused the accident by undertaking a dangerous flight manoeuver. Arguments such as previous nearmisses between a Chinese F- 8 jet, flown by the same pilot, and American spy planes, of which the military already had videotaped evidence, fueled this conviction. Other reasons were the size of both planes, since the lumbering US plane did not have the manoeuvrability of the Chinese jet, and the assumption that the American pilot would not imperil 24 crew members by veering into the Chinese fighter. The Chinese government, on the other hand, claimed they had proof of US responsibility, based on the particular damage to the surveillance plane.

Chinese fishing boat collision with Japanese coast guard patrol vessels near Diaoyutai islands (September 2010). On 7 September 2010 a Chinese fishing boat collided with two Japanese coast guard vessels near the Diaoyutai Island group claimed by China as well as Japan. The Chinese captain and crew were arrested, which inflamed anti-Japanese sentiment in China and led to public protests. ${ }^{3}$ The Chinese Ministry of Foreign Affairs issued a series of demands for the crew's release. On the diplomatic level, China summoned the Japanese ambassador in Beijing five times and called off planned negotiations about East China Sea gas fields. The Chinese trawler and the crew were released on
13 September. However, the captain was not set free until 25 September despite the restrained attitude by the Chinese authorities in calling for calm on the 18 September anniversary of the 1931 'Mukden Incident'. This event had led to the Japanese occupation of China's northeast and eventually the invasion of China. ${ }^{4}$ On 19 September a Japanese court announced a ten-day extension of the captain's detainment and its decision that prosecution would be held per domestic Japanese criminal law. At that point, the Chinese leadership took a firmer stance announcing retaliatory measures against Japan. For example, on 23 September, Chinese rare earth exports to Japan were stopped by the Chinese customs, ${ }^{5}$ and Japanese company employees working in China were captured with the argument they had entered forbidden military zones. When Sino-Japanese relations showed clear signs of deterioration, Tokyo eventually released the captain on 25 September.

Beijing perceived the fishing crew's arrest and the captain's prolonged detention as a unilateral break from the implicit arrangement of the status-quo around the troubled waters of the East China Sea (Jiang, 2010). Longstanding sovereignty disputes over the uninhabited Diaoyutai islands with a land area of $6.3 \mathrm{~km}^{2}$, along with overlapping claims to maritime space have been a source of regional contention over the years. Japan, China and Taiwan all refer to international treaties to validate their claims to sovereignty over the Islands. ${ }^{6}$ In the first half of the 1990s there was a brief easing of tensions because China adopted a more accommodating attitude as part of its diplomatic charm offensive toward Southeast Asia to assuage regional anxieties over China's growing military, political and economic power (Schofield and Storey, 2009). Following the enactment of the UNCLOS (United Nations Convention on the Law of the Sea) in 1994, which also called for establishing joint resource management, and its ratification by China and Japan in 1996, the status-quo set in with a Sino-Japanese fisheries agreement in 1997 and talks about joint exploration and development of potential oil and gas fields in the disputed waters. It meant a silent understanding that China, Japan and Taiwan all claim sovereignty over the islands, that Japan exercises administrative control and that its coast guards customarily drive away Chinese or Taiwanese fishing boats or protesters coming too close to the islets. But toward the end of the 1990s, disputes over unresolved territorial rights in the East China Sea and South China Sea once again evolved into hightension crises. Since then, China has continued to assert its power on the seas. Modernization of the Navy and development of the marine economy was presented as a priority at the launch of the 12th Five-Year Plan (2011-2015) and the 18th Congress of the Chinese Communist Party in November 2012 (Colin, 2016). Power relations are increasingly being played out in both the South China Sea and the East China Sea. China has constructed civilian and military infrastructure in the Spratly Islands (South China Sea) and Japan nationalized the Diaoyutai Islands in September 2012. Arbitration proceedings by the International Court of Arbitration in The Hague ruled against Chinese historical claim to the 'nine-dotted line' area (Ushaped line around the South China Sea) in favor of the Philippines in July 2016 (Perlez, 2016). Given the three Freedom of Navigation Operations (FONOP) held by the US between October 2015 and May 2016, the area does not only give rise to territorial disputes between neighbors, but has wider geopolitical implications, involving Sino-American strategic rivalry (Colin, 2016). Unsurprisingly, incidents such as the Chinese fishing boat collision with the Japanese patrol boat stir flurries of heated rhetoric from both sides. In this sense, the Diaoyutai islands have readily become a symbolic touchstone of both Chinese and Japanese nationalism. 
Continuity in discursive practices: empirical analysis of case studies 2001 and 2010

Findings of the empirical analysis of both studies ${ }^{7}$ are structured as follows. After a look at how the Self and the Other are positioned through categorization processes (4.1), illustrations are presented of other modes of ideological operation, like legitimation and reification (4.2). Parallels found in both studies about media representations of events that occurred with a nine-year time difference point at continuity in the discursive practice of Othering when it concerns international incidents involving China's sovereignty and safety of its citizens. Given the similarity of the incidents which both gave rise to a serious diplomatic impasse between major regional players, the discursive parallelism in both corpora is not unexpected. It shows a deep-rooted consistency in Chinese perception of the Self/Other.

Representation of Self/Other: polarized positioning of the two powers (China vs. US/Japan). This section demonstrates how the first level of positioning (Bamberg, 1997) operates by placing the actors in a certain relation toward each other. To see how the Self/ Other were positioned, lexical and syntactical choices were examined for the occurrence of semantic patterns. In the first case study, the US is portrayed as distant and arrogant, believing it need not adhere to international laws. Its attitude is perceived as a threat to Chinese security and sovereignty. China is the victim that deserves a sincere apology. ${ }^{8}$ It is depicted as a responsible stakeholder that treats the incident in a rational manner. ${ }^{9}$ As its negative mirror, the US is said to be "trying to evade the facts, shirk its responsibilities and shift the blame on to China". ${ }^{10}$ The narratives show a leaning toward the extremes of positive/negative portrayal of the Self/Other respectively. China is portrayed in a very positive way ${ }^{11}$ in 33 times, be it in headlines or full articles. This represents $14.1 \%$ of the total number of 233 texts. ${ }^{12}$ The US emerges very negatively in 106 accounts (45.4\%). Very negative news about the US thus outnumbers positive news about China. Overall, the US gets negative coverage in 134 texts (57.5\%) and Chinese actions receive laudatory comments in 39 narratives $(16.7 \%)$. Moderate criticism about Chinese reaction is apparent in two articles and only in one article is China depicted in negative terms. Yet, these are exceptions to an overall positive selfportrayal and negative other-presentation. This type of news coverage makes it hard for the reader not to empathize with China.

A transitivity analysis reveals a consistent pattern of Othering, noticed in headlines as well as in body texts. In the headlines, agency of a verbal process is given to China more often than to the US ( 74 and 53 times respectively), thus bestowing power upon China. The term China is used metonymically here, as it represents various actors. Twenty-four headlines featured the country China as actor, 18 headlines were reserved for the Chinese population (including overseas Chinese to present a general (even global) consensus among the population), 17 for an official institution or government figure and 13 for the family of the missing pilot. The Chinese media and a Chinese expert feature once as actor in the headlines. As concerns the US, 24 headlines present the country as actor, 20 reserve the acting position for official instances or government figures. Only in seven cases is the American plane the actor and most importantly, the American crew only feature in two headlines as the actors. As Entman (1991) pointed out when comparing news US news coverage of the Korean Airlines downing by a Soviet combat airplane in 1983 with a similar event involving Iran Air shot down by the US Navy in 1988, reference to the country instead of the particular actors is an oft recurring and generalizing tactic. This way, blame and responsibility can be elevated to the governmental or national level with repercussions for diplomatic relations between the parties involved. It lends the Chinese government more legitimacy to adopt the moral high ground and take a firm stance in urging an apology from the US side. This directive speech act appears in 8 out of 74 headlines, in which China is the actor with exhortative verbs such as 'demand', 'urge', 'call on'. The US, by contrast, only articulates demands in two out of 53 headlines. This way, the media ascribe China a dominant position as a powerful entity with the right to issue demands to the Other.

Results of the semantic analysis of the body texts indicate that the US is given a negative semantic role in 74 out of 76 articles. A pattern emerges because of a structural consistency putting the US as the actor of a verb with negative connotation, such as 'shirk its responsibility', 'rammed', 'damaged', 'violated', 'intruded into Chinese airspace', 'encroached upon Chinese sovereignty'. Repetition of this type of verbs strengthens the negative image of the US. This happens, for example, 13 times within the same news article on 3 April $^{13}$ and 24 times in a news article on 4 April $^{14}$ through a combination of negatively connotated verbs and repeated noun phrase constructions, such as 'an encroachment upon', 'violation', 'ramming of'. The accumulation of these structures contributes to the negative semantic field associated with US responsibility. In addition, certain labels add to the negative evaluative description of the US. Besides generalizing a particular incident, labels can also elicit a moral evaluation of an incident. Spread over 30 articles, the US gets a negative label 24 times. The notion, most prominently associated with the US, is 'hegemony', which is repeated 15 times. Other labels are 'culprit aircraft', 'aggressor', 'intruders'. Negative evaluative descriptions serve the same purpose. The US gets a negative assessment 68 times over 35 articles, in which 'hegemonic' is used 18 times. ${ }^{15}$ By reducing the US to the criminal aggressor, the audience is given a negative collective image about the US and can hardly imagine an alternative explanation.

Overlexicalization happens when a number of semantically related terms are repeated within one article. The semantic field for the US is related to 'law infringement' and 'threat to Chinese security', 'refusal to take responsibility'. By contrast, China is portrayed as a moral, responsible country with the right to claim an apology from the US. The following examples illustrate this point:

"In handling the issue, the Chinese government has adhered to the principled stance of safeguarding state sovereignty and national dignity and opposing hegemonism and power politics, it says. [...] The Chinese government has voiced solemn and just requests and protests to the US side and carried out a justified, advantageous and restrained struggle against US hegemonism, which has once again displayed the ability to cope with complicated situations and to handle complicated issues of the Communist Party of China Central Committee with Jiang Zemin at the core [...] The Chinese nation is a great nation which advocates justice and fears no powers" (comment "Turn Patriotic Enthusiasm into Strength to Build a Powerful Nation", in the People's Daily, on 11 April).

On 5 April, the People's Daily publishes a comment "Domineering Action and Hegemonic Logic", arguing that

"the Chinese people are a justice-upholding people. The Chinese people have the right to know the answers to these questions: $[\ldots]$ We sternly warn the US side that it should squarely face the fact, assume responsibility, and not absolve its domineering action with its hegemonic logic". 
In the news article "FM Spokesman gives full account of Air Collision", published in the People's Daily on 10 April, the Foreign Minister's Spokesman, Zhu Bangzao, reportedly

'urged the US side to make a prompt explanation to the Chinese government and people about the US plane's ramming of the Chinese jet and its infringement upon China's sovereignty and airspace, apologize to the Chinese side and shoulder all the responsibility arising from the incident'.

The spokesman reiterated that 'the Chinese government and people had the right to know the answers to the following questions $[. .$.$] .'$

The findings of the above syntactical and lexical analysis are corroborated by an examination of speech acts. As was already clear from the headline analysis, the importance of the directive speech acts can also be derived from the multiple instances of admonitions to the US in the body texts. On a daily basis, articles give the floor to Chinese as well as foreign statesmen and media for accusatory speech acts against the US. These voices urge the US to change their hegemonic attitude and show humility in apologizing. Many examples accumulate in the People's Daily's online version, which prints four articles on 4 April, seven articles the next day, and eleven on 6 April, all repeating the same claims and demands. ${ }^{16}$ Besides directives, the accounts are replete with deontic modality markers like 'should', 'must' in combination with 'apologize', 'bear full responsibility', 'learn to be humble'. The illocutionary force of admonitions stands out across the entire Chinese corpus. Modal epistemic adverbs, such as 'dang ran' [当然; surely] stress the common-sense and evidential nature of Chinese claims. These admonishments are premised on the assumption of US responsibility, and contribute to building up a general sense that a formal US apology is the only way this problem can be resolved.

The following quote illustrates the practice of positive Self and negative Other presentation, allowing the Chinese President, Jiang Zemin, to take the moral high ground in calling on the US to apologize,

"China has all along been dealing with the incident in a cool, responsible manner and with restraint, but the American side adopted an opposite attitude and methods. It has displayed an arrogant air, used lame arguments, confounded right and wrong and made groundless accusations against China." 17

These arguments set the overall tone for the legitimacy of the Chinese demand for an apology, which thus assumes a symbolic character to enhance the self-confidence of the Chinese people. Central in this discourse are the moral calls and exhortations, the accusatory diatribes against the hegemonic US threatening to harm the Chinese principles of territorial sovereignty and national dignity.

The second corpus, comprising the articles of the Chinese fishing boat collision with the Japanese coastal guard, which happened nearly a decade later, shows a similar pattern of stereotypical polarization within a victim/perpetrator framework. The ideological square becomes apparent in examples like:

"When we handled territorial disputes with Japan in the past, we always put China-Japan friendship at the highest priority. However, the DPJ [the ruling Democratic Party of Japan] administration does not have an effective strategy to support the development of the China-Japan relationship." 18

An abundance of adjectives with a negative denotation categorizes Japan into a particular social schema, allowing the reader to interpret the predicates according to their ideological dispositions. Hence, the writing becomes interpretative rather than straightforwardly factual. Descriptive adjectives, such as 'irresponsible', 'unreasonable', 'improper', 'reckless', as part of relational processes depicting Japan, serve to perpetuate the polarity between the two nations and import comment into factual stories. In the $R M R B$ the negative adjectives 'absurd', 'illegal', reserved for Japanese actors, are repeated 44 times in the corpus. As for predicational strategies, a transitivity analysis of relational and material processes reveals a diametrically opposed construction of both nations, which is a typical contextual strategy of a positive Self and a negative Other presentation. The use of material processes represented by transitive structures in the active voice facilitates biased evaluations about what the outgroup is doing to the in-group. A consistent negative agency role is allocated to Japan, which is accused of 'stubbornly acting as one wishes in a wilful manner' and of 'accumulating one mistake after the other'. ${ }^{19}$ Japan is made explicitly liable for damages, as the following example demonstrates,

“Japan's current government is now seriously endangering the relations by first producing the dispute, prolonging the row and keeping it unresolved, even threatening to put the Chinese captain of the trawler to a Japanese prison. Tokyo's unwise decision is diplomatically incendiary, politically gambling, and risks leaving a permanent damage to bilateral ties." 20

Negative properties of the Japanese culprit are contrasted with positive attributes of the Self. China is portrayed as the victim, entitled to utter directive speech acts in nearly every article. The Japanese ambassador was summoned six times by the Chinese Ministry of Foreign Affairs. The texts are also replete with expressive speech acts of condemnation and threats with verbs such as 'protest', 'condemn', 'oppose', which positions China as the moral superior party. Very often, the intensity of the speech act is reinforced by a modifying adverb such as 'urgently summons', 'strongly objects', ${ }^{21}$ which shows a persistent attitude. Despite its superior and at times threatening position, China is also reported to show its goodwill. It condemns radical actions against Japan and argues for further diplomatic negotiations. The Communist Party is lauded as the positive player, concerned about the safety of the Chinese people, for which they receive the people's gratitude. In a clever blending of the deictic reference 'our fishermen', a consensus or unity is reached between the government and its people, thus enhancing the feeling of group solidarity. The narratives reverberate with a nationalist spirit stemming from voices of compatriots inside and outside of China. Including international condemnation in the narratives lends legitimacy to the Chinese perspective.

Other discursive processes: dramatization, generalization, legitimation, reification. Besides articulating the protagonists in antagonistic positions, the following strategies are also salient in both case studies: (1) dramatization; (2) generalization of the event to the national level and embedding it within a historical perspective; (3) legitimation and reification (or naturalization) processes.

Narratives focus on the human aspect of the incident and give ample room to the family of the protagonists, the detained fishermen and captain in 2010 and the missing pilot in 2001. In the former case, Japan is made liable for the death of the captain's grandmother, who 'died from shock upon learning of the detention', which according to the author demonstrates that Japan is 'extremely inhumane'. ${ }^{22}$ Upon his return to China, the Chinese boat captain thanks the Party and the government for 
their loving care and expresses gratitude to his compatriots for their concern. ${ }^{23}$ Similarly, the overarching discourse topic in the spy plane corpus is the dramatic, personal loss of pilot Wang Wei. On 5 April, the People's Daily publishes an article, headlined "Wife of missing Chinese pilot accuses US of indifference to life" and the day after two articles appear, entitled "I'm proud of my son - Father of missing Chinese pilot" and "Mother of missing Chinese pilot hopes for his safe return", followed by an opinion article carrying the headline: "US 'Human Right' standard seen from incident of crash of Chinese Airplane". On the next day, several articles discuss the letter written by Wang Wei's wife to US president Bush. The pilot's wife gets plenty of media attention from her sick bed and the same gloomy picture is voiced by the son, who wants to see his missing father.

Besides highlighting the human aspect of both incidents, the newspapers also generalize the collision events to the national level. They thus achieve a type of narrativization which embeds the incidents in a broader historical perspective. In the boat collision case, China argues that "the use of force is a rude move by the Japanese authorities" ${ }^{24}$ and the spokeswoman Jiang $\mathrm{Yu}$ remarks that "people should remember and learn from history, and look at the future on the basis of history." 25 The problematic Sino-Japanese historical relations are often referred to, especially with the upcoming 79th anniversary of the Mukden incident in 1931, where the Japanese army detonated a part of the railway and used it as pretext to attack the city (Spence, 1999). ${ }^{26}$ Similarly, the spy plane collision is framed within the larger victimization narrative of the Chinese being humiliated by Western forces from the mid-nineteenth century Opium Wars onwards.

What appears endemic in the Chinese media narratives examined is the insistence on factuality and truth, which points at efforts to legitimize particular perspectives and reify contingent relations, structures and processes. In this practice, the second level of positioning (Bamberg, 1997) operates where the speakers position themselves in relation to their audience by convincing the latter of their truth claims and seeking authoritativeness. Legitimation is achieved through multiple references to international laws and treaties, references to experts, thereby changing footing from the journalist to a third authoritative party. All players involved in the dispute adopt judicial approaches, but interpret similar international treaties in different ways. Besides the judicial approach and footing shifts, narrativization and rationalization also contribute to legitimation of the own viewpoint. Rationalization is operationalized through the emphasis on facticity, while paradoxically remaining vague about the facts themselves. Additionally, a highly assertive mode is adopted through the discursive use of evidentiality in the absence of hedging devices and modal statements. This practice reifies or naturalizes fluid and unstable processes, which are portrayed as events of a quasi-natural kind so as to eclipse their social and historical character.

Modality concerns the expression of the mental attitude of the speaker towards the propositional content of his/her utterance, signaling factuality, evidentiality, eventuality, degrees of certainty, doubt, vagueness, probability and possibility, necessity, obligation, permission, and so forth. Expression of modality is the "producer's categorical commitment to the truth of the proposition" (Fairclough, 1989, p 29) and indicates his/her judgment on the credibility of the representation. It also signals degrees of directness and distance from the proposition. Depending on context, the use of a simple present can be employed to express or forge universal truths. Both epistemic and deontic modals are linguistic markers of persuasive expressions (Biber, 1988) and are often used to show one's authority. Predictions with definite future expressions like the emphatic high probability modal use of 'will' convey authority of statement and exclude a variety of possible scenarios. In combination with references to rationality, evidentiality, and with quotes of experts or 'world opinion', these claims serve to enhance authoritativeness of utterance and are powerful indicators of ideological investment.

For the first case-study, instances of legitimation and reification abound in the English-language China Daily. The naturalization process is realized by referring to factual truths, using emphatic negations or temporal adverbs at the extremes of gradable notions like 'never or always'. These all contribute to the boldness of assertion and invest a statement with a facticity guise. Authority of statement can also be conveyed through a simple present or past tense in the declarative mode. References to facts and epistemic modal adverbs serve to legitimize the Chinese perspective and present the argumentation as the indisputable and absolute truth. The following examples illustrate the abovementioned strategies: "The fact that the US plane rammed the Chinese plane is quite clear;" "Anyone with common sense can clearly see who should take responsibility"; ${ }^{28}$ "understand the true nature of the incident"; "the fact of the US plane's bumping into and destroying Chinese fighter jet is clear-cut and the US side cannot cover the truth"; "f0 "facts have proved once again"; 31 "the US surveillance aircraft obviously broke into China's territorial air space"32, "The Chinese side's legitimate request for an apology", ${ }^{33}$ "Washington always seeks to impose its hegemony on the whole world". ${ }^{34}$

Additionally, existential presupposition carriers, such as the definite article 'the', cleft constructions, and the possessive form (genitive and possessive pronoun) can invite the reader to accept certain assumptions as self-evident without adopting a critical attitude. The authors assume general audience acceptance of what is implicitly suggested. Examples of common-sense assumptions about the American Other are 'the desire to control the entire world', 'Washington's indifference'. ${ }^{36}$ The definite article 'the' and the possessive form 'Washington's' presuppose that the US has the desire to control the world and shows indifference. These presuppositions are not questioned, but positioned as facts. Here is an example of how, in the spy plane corpus, presupposition ('its'), choice of lexis ('ramming') and syntax (choice of transitive verb and positioning of agent and victim) cumulatively naturalize the US as the perpetrator: "Zhou reaffirmed China's solemn stand on the incident, demanding an explanation from the US side for its defiant acts of ramming and damaging a Chinese fighter jet over the South-China sea" ${ }^{37}$ (Lams, 2012, p 28).

The same strategies reappear in the corpus of the second casestudy. Bold assertions are made, mostly without argumentation. When these assertions are combined with the adjectives 'indisputable' or 'undeniable', each qualifying nouns like 'truth', 'sovereignty', a common-sense wisdom is encoded. If arguments are presented, they run against Japan's 'illegitimate' claim to the islands. They appeal on emotions and are based on historical material provided by authoritative experts. In the $R M R B$, three recurrent slogan-like expressions run as mantras through the corpus intending to guarantee an absolute truth. The first one holds that Diaoyutai Islands have been inherent part of Chinese territory since ancient times. Secondly, the reader is assured of the unswerving determination of the Chinese government to defend its right to sovereignty over the islands and finally, warnings are issued that China will resort to serious countermeasures with dire results for Japan. ${ }^{38}$ Again, China ascribes itself a high sense of justice and speaks with an authoritative voice. In the absence of mitigating modal devices or hedging particles, the dramatic nature of the event is emphasized through categorical assertions and maxim intensifiers, such as 'of course', deontic modal adverbs like 'necessary' and phrases such as 'no other possibility than', ${ }^{9}$ all claiming an indisputable truth. The Chinese government 
claims to be the legitimate owner of Diaoyutai. ${ }^{40}$ In the $R M R B$, there is no further argumentation, only repeated strong, factual assertions in the declarative mode with the simple present tense, such as "This is a fact that nobody can change. The Chinese side owns indisputable sovereignty over the Diaoyu Islands" ${ }^{41}$. Categorical assertions like these preclude any form of dialog. Less argumentation and fewer details are given in the Chineselanguage $R M R B$ than in the English-language People's Daily, which also gives the platform to experts supporting the official perspective and presents more historical documentation. This might be deemed necessary to convince its foreign readership.

\section{Discussion}

A brief contextualization of the narratives could be helpful to explain why the depiction of the main opponents, the US and Japan, turned out to be so antagonistic. Firstly, the US is disliked by the Chinese leadership for its foreign policy and military presence in the Asia-Pacific Region. In fact, many Chinese hold a dual image of the US, which is seen both as a beautiful imperialist and warmongering hegemon (Hao and $\mathrm{Su}, 2007$ ). While taking the US as reference point for Chinese modernization, they also view the US as the 'world police', seeking to undermine China's national security. Secondly, the Chinese reading of the event adopted a holistic approach to the incident in contextualizing the collision in a larger historical and political frame of the 'aggressive' Western powers bullying China from the mid-nineteenth century Opium Wars onwards. From this psychological mindset, China is said to react to foreign crises as a power that is not to be bullied, since it can no longer afford to lose its national dignity (Ho, 2015; Gries, 2004). It is the aggrieved psyche of a China being 'humiliated for 150 years' which lies at the basis of the 'victimization narrative' (Callahan, 2010; Lams, 2008) and the growing nationalist sentiment, which equally dominate media articles about other events in Chinese history of national and historical importance, such as the Hong Kong handover (Lams, 2008). Thirdly, the plane collision occurred at a politically sensitive time when the frequency of US surveillance flights had been increased, and when the new G.W. Bush administration was pursuing a National Missile Defense initiative that was viewed by the Chinese as potentially undermining their national security. During his presidential campaign, G.W. Bush had also repudiated former President Clinton's China policy of 'engagement' and declared China a strategic 'competitor'. Furthermore, the Chinese viewed this incident in a series of ambiguous incidents involving the US, which were all ascribed hostile intent or ulterior motives, such as the 1999 'accidental' bombing of the Chinese embassy in Belgrade by the American-led NATO operations in former Yugoslavia.

Similar arguments can be found for the negative depiction of Japan. The repeated friction between Japan and China concerning Chinese perceptions about Japanese lack of showing contrition for its past imperialistic behavior, the visits of Japanese prominent politicians to the Yasukuni shrine to honor the war dead including war criminals, the disputes concerning sovereignty over several island groups in the South China Sea, the Japanese security pact with the US and Taiwan in the AsiaPacific region all culminate in China's view of Japan as a threatening neighbor, yet a partner not to alienate for commercial reasons. As Vickers argues, "the early twenty-first century presents us with the spectacle of a Chinese society apparently more animated by anti-Japanese fervour than at any time since the 1940s" (2013, p 3). Vickers examines the extent to which the widespread anti-Japanese feelings can be seen as the outcome of an orchestrated program of political socialization or brainwashing. He argues that the "negative portrayal of Japan in official discourse should not be understood simply as the work of Svengalian apparatchiks", but also as "manoeuvres of political elites to reinforce their legitimacy". "Agency in shaping these perceptions", as Vickers puts it, "is distributed amongst those elites, the media, activist groups, and the wider pubic of Chinese societies, as well as actors within Japan itself" (Vickers, 2013, p 5). Also, the CCP leaders in the 1990s, who were in search for an "alternative to moribund state socialism", were able to readily tap into an "already-existing reservoir of popular antipathy towards Japan” (2013, p 3).

Sometimes, nationalist demonstrations against the foreign Other is condoned by the Chinese leadership. At other times, the government tones down nationalist rhetoric and calls on the public to keep its calm and refrain from violent outbursts of ultranationalism. This was the case with the Chinese boat collision with the Japanese patrol guard vessel, happening a few days prior to the sensitive anniversary of the Japanese invasion in China. The difference between the Chinese and English-language newspaper narratives reveals how the official media have to walk a thin tightrope between galvanizing patriotic fervour and not whipping up ultra-nationalist sentiments.

While the above contextualization offers a cultural-historical explanation for the type of discourse found in the narratives, one may still wonder whether the antagonist Othering practices are unique to China. On the basis of another comparative study the author conducted between Japanese and Chinese news accounts about points of contention between the countries, such as sovereignty claims to the Diaoyutai islands in the East China Sea, great parallelism was found between Chinese and Japanese discursive practices of Othering and Self-glorification. Naturally, one needs to take the different media institutional backgrounds into consideration. Unlike the Japanese news outlets, the Chinese newspapers are under state control. Yet, the great similarity between the Japanese and Chinese antagonist portrayals and legitimating discourses suggests that adopting 'positional superiority', in Saidian terms, is characteristic of any nation concerned about its national security and sovereignty. The discursive strategies appear to be inspired by sensations of threats to the national interests rather than mere culturalist ethnocentrism. Protectionist reactions and their discursive expressions are characteristic of nations across the globe and not unique to a certain country.

What stands out in the Chinese narratives, when compared with other national stories about the same events, is the hegemonic character of the discourse, the high degree of assertiveness in uttering truth claims and articulating directive speech acts. The Chinese official media adopt the moral high ground of authoritativeness in claiming the prerogative to the truth and naturalizing contingent perspectives. Black-and-white pictures, clad in wrong/right or true/false dichotomies are reminiscent of former dictatorial discourse. Apart from this political communist legacy, one could also explain the discourse as grounded in the Confucian culture of face-preservation. According to PLA General Liu Yuan, the Diaoyutai island conflict between China and Japan is a 'face problem' (Lin and Liguang, 2013).

While the analyst should approach the discourses within their cultural contexts, the question remains whether cultural background alone can explain the Chinese discourse. Would official and political elites in other Chinese communities, sharing similar Confucian cultural backgrounds but having experienced different socio-political histories, like the Hong Kong Chinese community, adopt similar discursive positions in conflicts with the foreign Other? Concerning various Chinese visions of Japan, Vickers argues that "the past casts pronounced if varied shadows over each Chinese community and the old [Japanese] enemy has come 
to occupy quite different positions in their national narratives" (2013, p 4).

A next question pertains to the applicability of the research method of Critical Discourse Analysis to the Chinese context. In the literature one can find an ongoing debate about universalistic and relativist approaches to discourse studies. Theoretical frameworks conceived in particular cultural and political contexts may not be a "natural vehicle through which people in other societies experience the world and articulate their feelings and visions" (Hall, 1992; Said, 1993; Shi-xu, 2009; in Cao, 2014, p 4). Therefore, the relevance and heuristic value of concepts developed in particular contexts can be questioned when imported into other contexts. Shi-xu (2009) argues for a "non-universalist, culturally inclusive diversification of discourse in communication across cultures" (Cao, 2014, p 4). These epistemological reflections within cultural discourse studies are legitimate and merit support, especially the need to consider contextual (including cultural) factors when doing media analysis. At the same time, political or ideological factors may also play a role in affirming national specificity or cultural characteristics in scientific discourse or in the drive to indigenize scientific disciplines. From that perspective, it is equally worth questioning the validity of epistemological relativism. Within a postcolonial spirit, Chinese leaders and academics alike have been engaging in a paradigmatic struggle with Western academic research paradigms to emancipate research on China away from a perceived 'colonial' tradition of Western humanities and social sciences to an indigenized framework.

A case in point is Shi-xu's (2012) argument that approaches like critical discourse analysis are marked by a Western worldview that draws up clear dichotomies, such as between reality and its representation, or between power and resistance (Schneider, 2013). The question is whether the linguistic tools utilized in critical discourse analysis (CDA) should also be discarded on the basis of CDA's Western origin and its implicit worldview. Tian and Chilton (2014) render a keen explanation of why the qualification of 'critical' in CDA reminds Chinese of the painful era of imposed critical self-reflection during the Cultural Revolution. The authors advance a compromise between the universalist and relativist approach in that the analyst should take an 'obtuse wider angle' (2014, p 198) to do critical discourse analysis in the Chinese context. This can happen by exploring the discourse functions in the socio-political transformations rather than taking a sharp, critical angle and fulfilling a political commitment, as in the traditional Western CDA approach. What should be clear is that perspectives and methods are only tools and are not ideological in themselves. It is how people apply them that matters (Schneider, 2013; Lee, 2001). In his discussion of methodological rigor in conducting a language-pragmatic analysis of discourse, Verschueren argues that, if the analyst adopts a rigorous method to detect ideological patterns emerging across various genres and at various structural levels, any researcher should be able to replicate the analysis with similar results (1999). What CDA analysts attempt to achieve is to "challenge dominant discourses, be they western or non-Western, and bring to light hitherto hidden, marginalized discourses, irrespective of culture" (Unger, 2006). Understandably, within the Chinese context of reduced freedom of expression, 'challenging' the official discourse is becoming increasingly difficult for Chinese CDA researchers.

\section{Conclusion}

Both case studies indicate that lexis, syntax, and modal structures join hands in cumulatively producing frames that run parallel with the Chinese national interest. The process of 'domesticating' news stories in accordance with the nation's foreign policy agenda is certainly not peculiar to the Chinese case and similar strategies are adopted by other national media outlets. ${ }^{42}$ Findings of each case-study are, to a certain extent, predictable, given the choice of case-studies examining sensitive issues of sovereignty. Any nation whose interest is at stake will react in defensive ways. But the systematicity and consistency of the discursive strategies over the years is quite revealing of how Chinese historical wounds at the hands of foreign powers do not seem to heal. The official media accounts are replete with antagonistic discourse about the foreign Other and glorification of the national Self. What stands out is the monoglossic nature of the discourse, and the high degree of assertiveness in uttering truth claims and articulating directive speech acts.

The following list outlines the most salient similarities between both case studies. It is by no means an exhaustive survey of all parallels. Firstly, linguistic categorizing processes position the powers as antagonists within a victim/aggressor framework. This points at the first level of the theoretical notion of positioning (Bamberg, 1997). The Chinese press depicts its in-group as morally superior, whereas the opponent is framed as the wrongdoer. The US and Japan alike are put in a negative semantic role by combining agency allocation in material action processes --imbued with negative lexical connotations-- and evaluative attribution of negative properties in representational strategies. China's self-presentation gets an authoritative aura because of its unquestioning perspective on China's positive and Western negative attributes and actions. It promotes the benign intents and efforts of the Communist Party while crowding out critical voices from within and outside of China. In this sense, preferred information is made prominent whilst the reverse is true for dispreferred information. Just as some Western 'China threat' literature is said to essentialize China as an externally knowable object, independent of historically contingent context or dynamic international interactions ( $\mathrm{Pan}, 2004)$, it can be argued that our sample of the Chinese state-run media, in a similar fashion, systematically reduces the US or Japan to the hegemonic aggressor by engaging in totalizing 'objectifications' of the Other. The ambiguity and changeable nature of identities belonging to the out-group are petrified or engraved into static and absolute differences from the in-group.

A second parallel is the positioning of China in a powerful role through the abundance of directive speech acts in both case studies. At this second theoretical level of positioning, the linguistic devices can be seen to operate as performance features that index how the utterer wants to be understood (Bamberg, 1997). China positions itself as the morally superior party entitled to urge either an apology or a gesture of conciliation from the opponent. Thirdly, the incidents are generalized to the national level by adopting a wider historical perspective. Action is ascribed to the US/Japan as nations instead of to the pilot of the US plane or the Japanese coastal patrol guard as individuals. A fourth similarity between the studies is the construction of a collective national identity by multiple deictic references ('us', 'our') and quotations of compatriots from within and outside of China, who in chorus condemn the foreign Other's actions. At this third level of positioning, the actor is actively constructing identities. Highlighting the human aspect of the incidents with an emphasis on the dramatic fate of the victims is yet another parallel strategy.

A sixth discursive pattern that shines most saliently through both studies is the practice of legitimation through references to international laws, domestic, as well as foreign experts and media supporting China's position. The seventh parallel is the reification process representing a transitory state of affairs as natural and permanent. Many common sense assumptions and presuppositions underlie the narratives, which in both cases present their interpretation of the events in the guise of explicit statements 
reverberating of epistemic certainty and references to facticity and truth. These strategies are employed by the Chinese narrator to take a position toward the reader/listener, which is the opponent in the dispute as well as the outside world that needs convincing of the Chinese perspective.

In conclusion, the above examples of identical linguistic strategies in both case studies demonstrate continuity of discursive practices in the official Chinese media within a time frame of nearly a decade, when it concerns reporting sensitive events that could destabilize Chinese perceptions of national sovereignty and security issues. From a theoretical perspective, findings have shown how narrative positioning is operational on all three levels in both case studies. The theoretical and methodological framework presented here serves to provide a handy tool for follow-up studies to analyze contemporary Chinese official media discourse about events involving China's engagement with multiple international actors. But, above all, attention should be drawn to the implication of persistent patterns in Chinese official media discourse in the first decade of this century, as this involves possible effects of commonsense assumptions underlying public communication on the media's readership. While the Chinese-language papers, targeting the domestic audience, stir up nationalist sentiment by defending the national flag, pointing at a growing trend towards popular nationalism, the English-language papers attempt to persuade the foreign audience of the Chinese position and take the moral high ground. The study signals to policy makers the continued historic enmity between China and Japan, the longstanding Chinese mistrust of Western powers, and above all the role these sentiments play in the public domain. Symbolic forms, when unquestioned, serve to establish and preserve relations of domination (Thompson, 1990). Clearly, power games are at work and discourse is readily deployed as a tool of persuasion. In Foucauldian terms, discourse is the power to be seized (Foucault, 1984). Hence, unraveling unquestioned truth claims in matters of sovereignty and security issues or representational practices about the Chinese Self and the foreign Other is undoubtedly of great importance for the international community to better understand Chinese strategic moves on the geopolitical chessboard.

Received: 9 March 2017 Accepted: 26 October 2017

Published online: 21 November 2017

\section{Notes}

1 'Diaoyutai' (or 'Tiaoyutai') is the Chinese reference to the island group, whilst 'Senkaku' is the Japanese term. Henceforth, only the Chinese term will be used in this article for uniformity.

2 For the Beijing Review, which is a weekly, article selection went up to 17 May 2001.

3 Leaked video footage about the Chinese trawler ramming the Japanese coast guard patrol was running on YouTube (https://www.youtube.com/watch? $v=o B-l A k-$ 9DNw).

4 This anniversary is usually commemorated with official mobilization of wartime memories, played out in the official media and gives rise to civilian anti-Japanese protests and demonstrations. Chants such as "Wipe out the Japanese devils" and stamping on Japanese flags are frequent on a sensitive anniversary like this (Scott McDonald (2010) "Chinese hold anti-Japan protests over boat dispute", China Post, 19 Sept).

5 Import of rare earth from China is essential for use in Japanese high-tech products such as superconductors and highbred cars (Jiang, 2010).

6 See, for example, the arguments published by the Society for the Dissemination of Historical Fact, "Incontrovertible Evidence: Five Pieces of Documentary Evidence Attest to Chinese Recognition of Japanese Sovereignty over the Senkaku Islands." http://www.sdh-fact.com/CL02_1/77_S4.pdf (17 August 2012).

7 The author's gratitude goes to her student, Céline Baeten, for conducting the analysis of the second case study.

8 An explicit example of the victim paradigm is the noun phrase: "China, the victim of the collision" (in "US grossly violated international law: signed article", China Daily, 4 April 2001.
9 A quote by the minister of Foreign Affairs Tang Jiaxuan illustrates this selfpresentation: "China has all along been dealing with the incident in a cool, responsible manner and with restraint", in "Jiang calls on US to apologize", CD Hong Kong edition, 5 April 2001.

10 "Evidence of hegemony: facts about the US reconnaissance plane colliding with a Chinese fighter", Beijing Review, 19 April 2001.

11 The determination of a (very) positive/negative, neutral leaning was determined as follows: 'very' was added when the story only featured positive/negative images without any counter-indication; the label 'neutral' was assigned for texts without any evaluation or with a balance between positive/negative elements.

12 Percentages were calculated for the English-language corpus of the first case study. The denominator was the total number of 233 objects of investigation, including 76 full-text articles and 157 headlines.

13 "Chinese official rebuffs US over air collision demand", China Daily, 3 April 2001.

14 "FM spokesman gives full account of air collision", China Daily, 4 April 2001.

15 Other negative predications for the US are "arrogant", 'provocative", hostile", "barbaric", etc.

16 These headlines illustrate this point: "US uses cold war language in spy plane incident, Castro says" (People's Daily online, 06 April 2001); "China has right to demand US apology for air collision: Syrian Daily" (China Daily, 05 April 2001); "Overseas Chinese make a statement and strongly condemn US hegemonic act" (Renminribao, 05 April 2001).

17 "Jiang calls on US to apologize", China Daily, 05 April 2001.

18 Zhao Chenyan (ed.) "Japan warned of strong response”, People's Daily, 20 Sept 2010 (Source: China Daily).

19 Author's translation from phrases such as “一意子瓜行”, “错上力口错”.

20 Li Hong, "Trawler row should be a non-starter", People's Daily, 13 Sept 2010.

21 Translated from phrases, such as “紧急吕见”, “严重抗议”.

22 "Japan's actions over Diaoyu Islands defy facts, draw protests", People's Daily, 21 Sept. 2010.

23 Author's translation from “感谢党和政府的关怀, 感谢祖国人民对我的关心”, RMRB, 26 Sept. 2010 .

24 "Diaoyu islands collision a dangerous game", People's Daily Editorial, 9 Sept 2010.

25 “China warns Japan's detention of captain will sour ties, People's Daily, 17 Sept 2010. This argument is also echoed on the website of the Chinese Ministry of Foreign Affairs.

26 The slogan "Don't forget national humiliation, don't forget September 18" of a Chinese demonstrator is a popular quotation in the papers.

27 "Chinese official rebuffs US over air collision demand", China Daily, 3 April 2001.

28 "US excuses betray its weaknesses", China Daily, 3 April 2001.

29 "US plane grossly violated international law: signed article", China Daily, 4 April 2001.

30 "FM spokesman voices China's full stance on collision incident", China Daily, 4 April 2001.

31 "Hong Kong media blame US for plane collision", China Daily, 4 April 2001.

32 "Chinese people indignant at US plane intrusion", China Daily, 4 April 2001.

33 "China Daily Commentary: crisis benefits none", China Daily, 4 April 2001.

34 "Kenyan newspaper criticizes US as known aggressor", People's Daily, 5 April 2001.

35 "China has right to demand US apology for air collision: Syrian Daily", China Daily, 5 April 2001.

36 "US excuses betray its weaknesses", China Daily, 3 April 2001

37 "Chinese official rebuffs US over air collision demand", China Daily, 3 April 2001.

38 Jiang Yu, "Japan will reap as it has sown, People's Daily, 11 Sept. 2010.

39 Author's translation from “不得不'. The following sentence gives another illustration of a common-sense assumption the author thinks s/he shares with the readers: “中方 (...) 当然要作出必要回应” [The Chinese side obviously has to deliver the necessary response], RMRB, 23 September 2010.

40 Claimed by Jiang Yu, in the article by Peng Min (彭敏) “Waijiaobu juxing lixing jizhehui” 外交部 举行例行记者会 [the Ministry of Foreign Affairs holds a press conference], RMRB, 15 September 2010.

41 Author's translation from “这一事实是任何人都无法改变的 。中方对钓鱼岛拥有无可争辩的 主权”, RMRB, 15 September 2010.

42 The process of 'domestication' is defined in terms of treatment of international news as a variation of domestic themes in consonance with national interests and the foreign policy agenda of home countries (Lent, 1977).

\section{References}

Allan S (1999) News culture. Open University Press, Milton Keynes

Bamberg M (1997) Positioning between structure and performance. J Narrative Life Hist 7(1-4):335-342

Biber D (1988) Variation across speech and writing. Cambridge University Press, Cambridge

Brantlinger P (1990) Crusoe's footprints: cultural studies in Britain and America. Routledge, London

Cao Q (2014) Legitimisation, resistance and discursive struggles in contemporary China. In: Cao Q, Tian HL, Chilton P (eds) Discourse, politics and media in 
contemporary China. John Benjamins Publishing Company, Amsterdam/ Philadelphia/, p 1-21

Callahan W (2010) China: the pessoptimist nation. OUP, Oxford

Carvallo A (2008) Media(ted) discourse and society: rethinking the framework of critical discourse analysis. J Stud 9(2):161-177

Colin S (2016) Editorial to Special Feature: China's policy in the China Seas: sovereignty, security, and cooperation. China Perspect 3:5

Edgar A, Sedgwick P (1999) Key concepts in cultural theory. Routledge, London

Entman R (1991) Framing US coverage of international news: contrasts in narratives of the KAM and Iran air incidents. J Commun 41(4):6-27

Fairclough N (1989) Language and power. Longman, London

Foucault M (1984) The order of discourse. In: Shapiro M (ed) Language and politics. Basil Blackwell, p 108-138, (Ian McLeod Trans.)

Gries PH (2004) China's new nationalism: pride, politics, and diplomacy. University of California Press, Berkeley

Hall S (1992) The West and the rest: discourse and power. In: Hall S, Gieben B (eds) Formations of modernity. Polity, Cambridge, p 275-332

Halliday M (1978) Language as social semiotic. Edward Arnold, London

Halliday M (1994) Introduction to functional grammar, 2nd edn. Arnold, London

Hao YF, Su L (2007) Beautiful imperialist or warmongering hegemon? Contemporary Chinese views of the US. In: Farber D (ed) What they think of Us: International perceptions of the U.S. since 9/11. Princeton University Press, Princeton, p 74-94

Hartley J (1982) Understanding news. Routledge, London and NY

Ho BTE (2015) About Face-the relational dimension in Chinese International Relations discourse. J Contemporary China 25(98):1-14

Jiang WR (2010) New Twists over old disputes in China-Japan relations. China Brief, 10 (20), http://www.jamestown.org/uploads/media/cb_010_37b83a.pdf. Accessed 3 Nov 2010

Laclau E, Mouffe C (1985) Hegemony and socialist strategy: toward a radical democratic politics. Verso, London

Lams L (2008) Embedded identity building in Chinese/Taiwanese English-language press narratives. In: Carpentier N, Spinoy E (eds) Discourse theory and cultural analysis, media, arts and literature. Hampton Press, Cresskill, NJ, p 71-94

Lams L (2010) Reconnecting theories of language pragmatics and critiques on logocentric methodological approaches to media discourse analysis. Romanian Rev Political Sci Int Relat 7(1):94-110

Lams L (2012) Communication and difference: one event-different media frames. A discursive analysis of US and Chinese media narratives about the 2001 Hainan Incident. In: Hernandez L (ed) China and the West: Encounters with the other in culture, arts, politics and everyday life. Cambridge Scholars, Newcastle upon Tyne, p 17-32

Lams L (2014) Strategies of symbolic meaning construction in Chinese official discourse. In: Lams L, Crauwels G, Serban HA (eds) Totalitarian/Authoritarian discourses-a global and timeless phenomenon? Peter Lang, Bern, p 185-217

Lee CC (2001) Rethinking the political economy: implications for media and democracy in greater China. The Public 8(3):1-22

Lent JA (1977) Foreign news in American media. J Commun 27:46-50

Levinson SC (1983) Pragmatics. Cambridge University Press, Cambridge

Lewis M (2002) An analysis of state responsibility for the Chinese-American airplane collision incident. NY Univ Law Rev 77:1404-1441

Lin B and Liguang Y (2013) When will soldiers show sword? http://news. xinhuanet.com/2013lh/2013-03/16/c_115041700.htm. Accessed 11 May 2014

McDonald S (2010) Chinese hold anti-Japan protests over boat dispute. China Post, Sept 19. Accessed 20 September 2010

Mey JL (2001) Pragmatics: an introduction, 2nd edn. Blackwell Publishing, Oxford

Pan CX (2004) The 'China Threat' in American self-imagination: the discursive construction of 'Other' as power politics. Alternatives 29:305-331

Perlez J (2016) Tribunal rejects Beijing's Claims in South China Sea. New York Times, 12 July 2016. https://wwwnytimes.com/2016/07/13/world/asia/southchina-sea-hague-ruling-philippines.html?_r=o. Accessed 18 July 2016

Said E (1993) Culture and imperialism. Alfred A. Knopf, New York, NY

Said E (2003) [1978] Orientalism. Penguin Books, London

Shi X (2009) A cultural approach to discourse. Palgrave Macmillan, Basingstoke and New York

Shi X (2012) Understanding Contemporary Chinese Political Communication - A historico-intercultural analysis and assessment of its discourse of human rights. J Lang Polit 11(1):93-114
Schneider F (2013) Is discourse analysis a 'western' project? Politicseastasia October 28, 2013. http://www.politicseastasia.com/research/fourthinternational-conference-on-multicultural-discourse/. Accessed 1 Nov 2013

Schofield C, Storey I (2009) The South China Sea dispute: increasing stakes and rising tensions. Jamestown Foundation Report, Nov 20. http://www.jamestown.org/programs/recentreports/single/?tx_ttnews[tt_news] =35758\&tx_ttnews[backPid] $=63 \&$ cHash=29001f84fa. Accessed 17 Aug 2012 .

Spence J (1999) The search for modern China. W.W. Norton \& Company, London/NY

Tian HL, Chilton P (2014) Issues in discourse approach to social transformations in China: a synopsis. In: Cao Q, Tian HL, Chilton P (eds) Discourse, politics and media in contemporary China. John Benjamins Publishing Company, Amsterdam/Philadelphia/, p 195-207

Thompson JB (1990) Ideology and modern culture. Critical social theory in the era of mass communication. Polity, Cambridge

Thompson JB (1995) Media and modernity: a social theory of the media. Polity, Cambridge

Unger J (2006) A cultural approach to discourse by Shi-Xu-a review. Lang Soc 35 (4):617-620

Van Dijk T (1989) Social cognition and discourse. In: Howard G, Robinson WP (eds) Handbook of social psychology and language. Wiley, Chichester, p 163-183

Van Dijk T (1995) Discourse semantics and ideology. Discourse Soc 6(2): 243-289

Van Dijk T (1998) Ideology: a multidisciplinary approach. Sage, London

Van Leeuwen T, Wodak R (1999) Legitmizing immigration control. A discoursehistorical analysis. Discourse Stud 1(1):83-118

Verschueren J (1999) Understanding pragmatics. Arnold Publishers, London, New York

Verschueren J (2001) Predicaments of criticism. Crit Anthropol 21(1):59-81

Vickers E (2013) Editorial: Chinese visions of Japan: official narratives of a troubled relationship. China Perspect 4:3-5

Wodak R, de Cillia R, Reisigl M, Liebgart K (1999) The discursive construction of national identity. Edinburgh University Press, Edinburgh

\section{Data availability}

The datasets employed and analyzed during the current study were derived from the following public domain resources:

http://www.people.com.cn/

http://en.people.cn/

http://www.chinadaily.com.cn/en/

http://www.bjreview.com.cn/Cover_Story_Series_2010/node_35862.htm

\section{Additional information}

Reprints and permission information is available online at http://www.nature.com/ reprints

Publisher's note Springer Nature remains neutral with regard to jurisdictional claims in published maps and institutional affiliations.

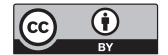

Open Access This article is licensed under a Creative Commons Attribution 4.0 International License, which permits use, sharing, adaptation, distribution and reproduction in any medium or format, as long as you give appropriate credit to the original author(s) and the source, provide a link to the Creative Commons license, and indicate if changes were made. The images or other third party material in this article are included in the article's Creative Commons license, unless indicated otherwise in a credit line to the material. If material is not included in the article's Creative Commons license and your intended use is not permitted by statutory regulation or exceeds the permitted use, you will need to obtain permission directly from the copyright holder. To view a copy of this license, visit http://creativecommons.org/ licenses/by/4.0/

(C) The Author(s) 2017 